\title{
Transport of soil and nutrients by wind in bush fallow land and traditionally managed cultivated fields in the Sahel
}

\author{
Charles L. Bielders ${ }^{\mathrm{a}, *}$, Jean-Louis Rajot ${ }^{\mathrm{b}}$, Moustapha Amadou ${ }^{\mathrm{c}}$ \\ aCRISAT, B.P. 12404, Niamey, Niger \\ ${ }^{\mathrm{b}}$ IRD, LISA, University Paris 12, France \\ ${ }^{\mathrm{c}}$ INRAN, B.P. 429, Niamey, Niger
}

Received 16 May 2001; accepted 28 February 2002

\begin{abstract}
In the West African Sahel, few direct measurements are currently available for the major land-use types on the extent of soil losses by wind erosion. A measurement campaign was therefore carried out in 1997 to monitor windblown sediment fluxes using Big Spring Number Eight (BSNE) sand-traps in a conventionally managed cultivated field and bush fallow in western Niger. Sediment balances were derived from the measured windblown sediment mass fluxes. Results indicate that sediment fluxes in a cultivated field increased linearly over distances up to $76 \mathrm{~m}$ irrespective of wind speed and duration. Sediment deposition over distances up to $47 \mathrm{~m}$ in an adjacent bush fallow was well described by an exponential decay function with a near constant trapping efficiency coefficient of $0.11 \mathrm{~m}^{-1}$ for incoming sediment mass fluxes between 10 and $45 \mathrm{~kg} \mathrm{~m}^{-1}$. Soil mass balances up to -17.5 and +10.5 $\mathrm{Mg} \mathrm{ha}^{-1}$ were measured in a single storm in the field and fallow, respectively. However, $89 \%$ of the sediment deposition observed in the fallow occurred within the first $20 \mathrm{~m}$. The nutrient content of windblown sediment generally declined with distance into the field and increased with distance into the bush fallow. Because of the low nutrient content of the native soil, total nutrient losses remained very low $\left(<163 \mathrm{mg} \mathrm{m}^{-2}\right.$ for any given nutrient). However, such losses were by no means negligible compared to the average nutrient uptake by a millet crop. The present measurements confirm that wind erosion can result in substantial soil losses in traditionally managed fields on the sandy soil of the Sahel. The bulk of sediment transport is, however, predominantly short range as the saltating material is efficiently trapped by the natural vegetation of fallow land. (C) 2002 Elsevier Science B.V. All rights reserved.
\end{abstract}

Keywords: Wind erosion; Nutrient loss; Vegetation; Land degradation; Sand catcher; Enrichment ratio

\footnotetext{
* Corresponding author. Department of Environment Science and Land Use Planning, Université catholique de Louvain, Croix du Sud 2/2, B-1348, Louvain-la-Neuve, Belgium. Tel.: +32-10-473714; fax: +32-10-473833

E-mail address: bielders@geru.ucl.ac.be (C.L. Bielders)
} 


\section{Introduction}

In the Sahelian zone of West Africa, ongoing land degradation and the resultant loss of the soil's productive capacity constitute a major concern to the local populations and the international community alike (Bielders et al., 2001; Sivakumar et al., 1998; Sterk and Haigis, 1998). Among the land degradation processes, wind erosion is regarded as a major contributor in this region (Mainguet and Chemin, 1991).

Although the occurrence of wind erosion in the Sahel is indisputable, the extent and impact of this long-term cumulative process (Mainguet, 1998) on soil productivity is difficult to quantify at all but the most local scale. In Niger in particular, where the dominant sandy soils of aeolian origin are highly susceptible to wind erosion (Gavaud, 1977), most estimates of wind erosion are based either on subjective expert knowledge (Middleton et al., 1997) or on plot scale (less than 0.5 ha) measurements within controlled field experiments which seldom reflect the management practices of small-holder farmers in Niger (Bielders et al., 2000; Buerkert and Lamers, 1999; Michels et al., 1995; Sterk et al., 1996). Indeed, the latter studies invariably involved much higher planting densities as well as better and more timely crop management and weed control operations than would be the case for conventionally managed fields. In addition, they frequently involved unrealistic crop residue mulching rates and sometimes the use of mineral fertilizers. As a consequence, the estimates of soil and nutrient losses by wind erosion derived from such experiments cannot readily be extended to agricultural land under traditional management conditions in western Niger.

Using the ${ }^{137} \mathrm{Cs}$ methodology, Chappell et al. (1998) reported soil losses of $48.5 \mathrm{Mg}$ ha $^{-1}$ year $^{-1}$ over a 30 -year period, averaged over a $0.5-\mathrm{km}^{2}$ study area in western Niger. This is in contrast with the results of Rajot (2001) who estimated on the basis of a mass balance for wind blown dust particles smaller than $20 \mu \mathrm{m}$ that under present land-use conditions the mass balance is positive at $0.36 \mathrm{t} \mathrm{ha}^{-1}$ year ${ }^{-1}$. These latter calculations applied to an area $25 \mathrm{~km} \times 25 \mathrm{~km}$ in size encompassing the study area of Chappell et al. (1998). Deposition and erosion of suspended dust-size particles $(<20 \mu \mathrm{m})$ on sandy soils of western Niger is only of the order of $0.5-2 \mathrm{tha}^{-1}$ year ${ }^{-1}$, even on cultivated fields which represent the most erodible condition of all land units in the area (Drees et al., 1993; Herrmann, 1996; Rajot, 2001). The loss of dust-size particles cannot therefore explain the large erosion rates reported by Chappell et al. (1998). Besides the fact that the calculated net soil mass balance may be influenced by water erosion to a greater extent than acknowledged by these authors, the discrepancy between the studies of Chappell et al. (1998) and Rajot (2001) could therefore possibly only be explained by the occurrence of large soil losses resulting from saltating and reptating sediment transport.

Based on the site map provided by Chappell (1996) and the land-use map for a nearby watershed (Manu et al., 1991), one can estimate that approximately $40 \%$ of the area studied by Chappell et al. (1998) was occupied by bush fallow vegetation on sandy soils and by a ferricrete-capped plateau with banded "Tiger bush" vegetation and gravelly loam soil. For all practical purposes, these two land units can be considered non-erodible (Rajot, 2001; Chappell et al., 1998). The high percentage of non-erodible land in the study area therefore implies that the transport of saltating and reptating particles should have resulted in the short-distance transfer of sediment from erodible cultivated fields to adjacent non- 
erodible land units rather than in a long distance transport as suggested by the high soil erosion rates reported by Chappell et al. (1998). At present, however, no data are available concerning the trapping efficiency of bush vegetation for the Nigerien Sahel with respect to saltating and reptating particles.

The present study was carried out in the Sahelian zone of Western Niger with a dual purpose. First, near-surface wind blown sediment fluxes were monitored for a 2-month period in 1997 in a farmer's field in order to perform an initial assessment of soil and nutrient balances for traditionally managed cultivated land. Second, sediment fluxes were also monitored in an adjoining bush fallow in order to assess the becoming of wind blown sediment and nutrients eroded from cultivated fields when this sediment is transported into bush fallow land.

\section{Materials and methods}

\subsection{Site description}

The experimental field was located in western Niger near the village of Banizoumbou $\left(13^{\circ} 31^{\prime} 8^{\prime \prime} \mathrm{N}, 2^{\circ} 39^{\prime} 5^{\prime \prime} \mathrm{E}\right)$, approximately $60 \mathrm{~km} \mathrm{E}$ of the capital city Niamey (Fig. 1). Average annual rainfall is ca. $500 \mathrm{~mm}$. The climate, as in most of the Sahel, is characterized by a prolonged dry season from October to May. During this period northeasterly "Harmattan" winds occur, but these are less erosive than the easterly convective storms typically observed immediately prior to, and during, the growing season from May to

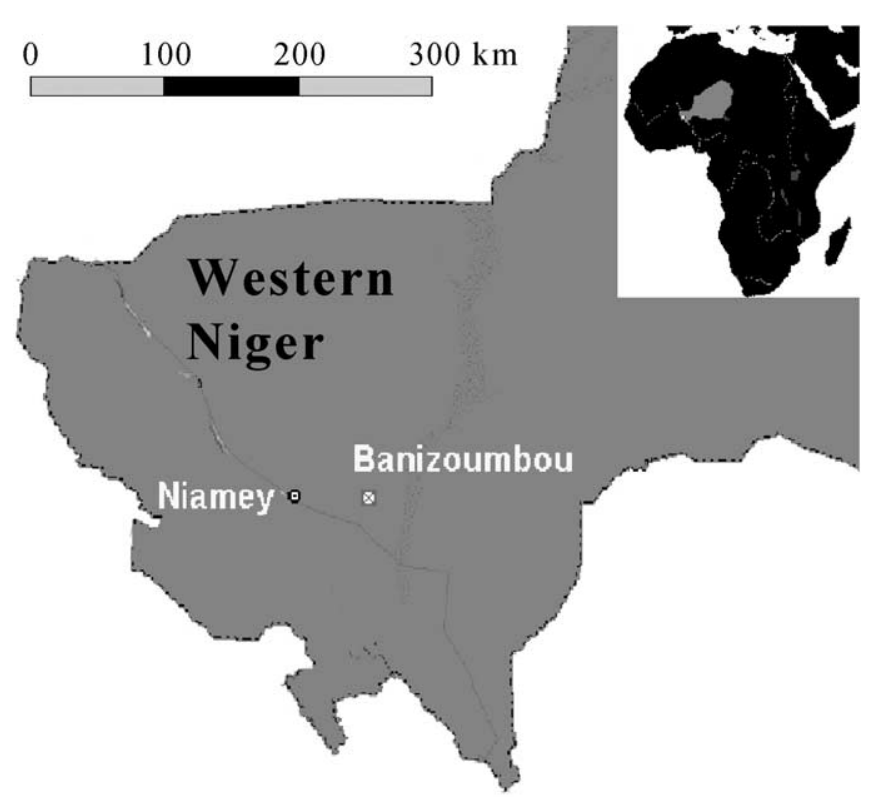

Fig. 1. Location of the village of Banizoumbou in western Niger. 
September (Michels et al., 1995; McTainsh and Walker, 1982). The soil at the experimental site is classified as a psammentic Paleustalf with $95 \%$ sand and $3 \%$ clay in the top $0.05 \mathrm{~m}$ (Bielders et al., 2000).

A farmer's field was selected in 1997 in a wide sandy valley bottom plain to the West of the village. The field was selected because of its large size, flat topography and the fact that it was bordered on several sides by bush fallow land that could be considered a priori to be non-erodible land on the basis of litter and vegetation cover. The bush fallow land extended for more than $100 \mathrm{~m}$ on the northeastern, northern and western side of the cultivated field, and was composed of a dense herbaceous vegetation cover as well as open bushy vegetation dominated by Guiera senegalensis (approx. 1 bush per $100 \mathrm{~m}^{2}$ ). The cultivated field had been cropped for more than 5 years prior to the experiment and was cropped at a low planting density $\left(<5000\right.$ planting holes $\left.\mathrm{ha}^{-1}\right)$ with a mixture of millet [Pennisetum glaucum], cowpea [Vigna unguiculata] and sorrel [Hibiscus sabdarifa] in 1997. Throughout the growing season the field was managed in the traditional way by the farmer, which consisted solely of manual sowing and harvest of the crops, and of two manual weeding operations using a handheld "hilaire" hoe. No fertilizer had been applied to the field.

\subsection{Measurements}

Sandstorms were monitored during a 2-month period from 18 June until 15 August 1997. Soil mass flux densities were measured using conventional Big Spring Number Eight (BSNE) sand-traps (Fryrear, 1986) with $0.001 \mathrm{~m}^{2}$ vertical openings placed 0.1 and $0.35 \mathrm{~m}$ above ground. On the northeastern boundary, sand-traps were installed into the field at 0,10, 20, 40 and $80 \mathrm{~m}$ from the field boundary along 2 (before 26 July) or 3 (after 26 July) east-west-oriented transects spaced $10 \mathrm{~m}$ apart. On the western side, sand-traps were equally installed into the bush fallow at $0,5,10,20$ and $40 \mathrm{~m}$ from the field boundary along three east-west-oriented transects spaced $10 \mathrm{~m}$ apart. Sand-traps were placed at two additional locations along the field boundary. The length of the transects in the field and bush fallow was dictated by limitations on the number of sand-traps available. The orientation of the transects was chosen so as to correspond to the average wind direction of the easterly convective storms that result in the most intensive erosion in Western Niger (Michels et al., 1995).

Sediment was collected from the sand-traps after each storm and dried at $105{ }^{\circ} \mathrm{C}$. Sediment mass fluxes $\left(q ;\left[\mathrm{kg} \mathrm{m}^{-1}\right]\right)$ at each measurement location were calculated for each storm by assuming unit trapping efficiency of the sand-traps and fitting a power function of the type:

$$
q=a\left(1+\frac{z}{\alpha}\right)^{b}
$$

to the 0.10 and $0.35 \mathrm{~m}$ height $(z ;[\mathrm{m}])$ mass flux density data (Zingg, 1953). Eq. (1) was then integrated between 0 and $0.35 \mathrm{~m}$ height. In Eq. (1), $a, \alpha$ and $b$ are fitting parameters, with $a \geq 0$ corresponding to the mass flux density at the soil surface $\left[\mathrm{kg} \mathrm{m}^{-1}\right]$ and $\mathrm{b}$ a dimensionless parameter that is $<0 . \alpha\left[\mathrm{m}^{-1}\right]$ was assumed to be equal to 1 (Sterk and Raats, 1996). 
Wind velocity and direction were recorded automatically for each storm at a weather station located approximately $1 \mathrm{~km}$ north of the experimental field. Both wind speed and direction were measured every second and recorded as 5-min averages. Standard deviation of wind speed was calculated based on the 5-min averages whereas for wind direction the standard deviation was calculated as the mean value of the standard deviation recorded for each 5-min interval. Average wind speed and direction at $2 \mathrm{~m}$ above ground were calculated for each storm and only for the period preceding rainfall during which saltation occurred, as described by Bielders et al. (2000). In case two sandstorms occurred within the same day, the sand flux data was discarded, unless one of the two sandstorms clearly dominated the other in duration and average wind velocity. In such cases, the average wind direction of the most intense storm was taken into account.

Sand-trap location as well as boundaries of the experimental field were mapped using a differential global positioning system (GPS) receiver. For each storm, the distance between the sand-traps and the nearest field boundary along the streamwise direction of the wind was derived from the map. Soil loss or deposition was calculated from the change in sediment mass fluxes with distance.

Soil samples for chemical analysis were taken on 22 October 1997 to a depth of $0.02 \mathrm{~m}$ within the area delimited by the three sand-trap transects in the field and in the bush fallow. One composite sample was taken for each of the following distances into the field: $0-10$, 30-40, and 60-70 m. Composite samples were also taken for each of the following distances into the bush fallow: $0-5,5-10,10-20$, and 30-40 m. All samples were analyzed for $\mathrm{pH}\left(1: 2.5 \mathrm{H}_{2} \mathrm{O}\right)$, available phosphorus (Bray-1; Olsen and Sommers, 1982), organic C (dry combustion; Nelson and Sommers, 1982), and total nitrogen (Kjeldahl procedure; Bremmner and Mulvaney, 1982). Exchangeable bases (Ca, $\mathrm{Mg}, \mathrm{Na}, \mathrm{K}$ ) were determined after displacement by $\mathrm{NH}_{4} \mathrm{OAc}$. $\mathrm{Ca}$ and $\mathrm{Mg}$ were determined by atomic absorption spectrophotometry, whereas $\mathrm{Na}$ and $\mathrm{K}$ were determined using flame photometry. Soil particle-size analysis was carried out on the $<2-\mathrm{mm}$ fraction by sieving for determination of the sand fraction $(50-2000 \mu \mathrm{m})$ and by the pipette method for the silt $(2-50 \mu \mathrm{m})$ and clay fractions $(<2 \mu \mathrm{m}$; Gee and Bauder, 1986).

Chemical analyses were carried out on the sediment samples of the sand storms of 21 June, 30 June, and 26 July 1997 for the sand-traps located 0, 40, and $80 \mathrm{~m}$ into the field and $0,5,10$ and $40 \mathrm{~m}$ into the bush fallow. Sediment samples from the traps located at the same distance into the field or bush fallow were pooled, but the analysis was carried out separately for the 0.10 - and $0.35-\mathrm{m}$ height sand-traps. Samples were analyzed for total N, $\mathrm{P}, \mathrm{K}, \mathrm{Ca}$ and $\mathrm{Mg}$ content (Houba et al., 1995). For some samples, the amount of material was insufficient and therefore chemical analyses could be performed for only a subset of nutrients, if at all.

Nutrient balance calculations were carried out by assuming a power function relationship between nutrient content $\left(C ;\left[\mathrm{mg} \mathrm{kg}^{-1}\right]\right)$ and height above ground $(z ;[\mathrm{m}])$ :

$$
C=m z^{n}
$$

where $n[-]$ and $m\left[\mathrm{mg} \mathrm{kg}^{-1}\right]$ are positive regression coefficients (Zobeck and Fryrear, 1986; Leys and McTainsh, 1994). This equation was fitted to the total nutrient content measurements of the sediment collected in the sand-traps at 0.1 and $0.35 \mathrm{~m}$ height. 
Nutrient fluxes $\left[\mathrm{kg} \mathrm{m}^{-1}\right]$ where calculated by multiplying the mass flux profile (Eq. (1)) by the nutrient content profile (Eq. (2)) and integrating the resulting equation numerically between 0 and $0.35 \mathrm{~m}$ height (Sterk et al., 1996).

\section{Results and discussion}

Sixteen sand storms were recorded between 18 June and 15 August 1997. However, only a subset of events could be used for sediment mass balance calculations depending on average wind direction during the sand storm with respect to field or bush fallow boundaries (Table 1). In the field, only storms with wind directions comprised between $0^{\circ}$ and $90^{\circ}$ could be considered (North $=0^{\circ}$, measured clockwise). In the bush fallow, calculations were restricted to storms with wind directions comprised between $55^{\circ}$ and $140^{\circ}$.

\subsection{Sediment fluxes}

\subsubsection{Cultivated field}

A linear increase in sediment flux was observed consistently in the field for all suitable events irrespective of wind speed (six events; Fig. 2a and Table 2). Sediment fluxes entering from the bush fallow were generally $<2 \mathrm{~kg} \mathrm{~m}^{-1}$ at the field boundary, except for

Table 1

Average wind velocity and direction at $2 \mathrm{~m}$ height and duration of saltation for the events recorded between 18 June and 15 August 1997

\begin{tabular}{lcclll}
\hline Date & $\begin{array}{l}\text { Speed }^{\mathrm{a}} \\
\left(\mathrm{m} \mathrm{s}^{-1}\right)\end{array}$ & $\begin{array}{l}\text { Direction }^{\mathrm{a}} \\
\left.{ }^{\circ}\right)\end{array}$ & $\begin{array}{l}\text { Duration } \\
(\mathrm{h}: \mathrm{min})\end{array}$ & \multicolumn{2}{l}{ Mass balance calculation in } \\
\cline { 5 - 6 } $21 / 06^{\mathrm{b}}$ & $13.0( \pm 1.8)$ & $56( \pm 7)$ & $00: 30$ & Field & Bush fallow \\
& $9.1( \pm 0.7)$ & $358( \pm 8)$ & $00: 20$ & & Yes \\
$23 / 06$ & $11.7(\mathrm{~N} / \mathrm{A})$ & $133( \pm 7)$ & $00: 05$ & No & Yes \\
$27 / 06^{\mathrm{b}}$ & $7.8( \pm 0.7)$ & $178( \pm 7)$ & $00: 25$ & Yes & Yes \\
& $9.6( \pm 1.8)$ & $65( \pm 9)$ & $00: 25$ & & Yes \\
$30 / 06$ & $14.0( \pm 0.5)$ & $82( \pm 10)$ & $00: 10$ & Yes & Yes \\
$07 / 07$ & $9.0(\mathrm{~N} / \mathrm{A})$ & $104( \pm 9)$ & $00: 05$ & No & Yes \\
$10 / 07$ & $9.4( \pm 0.6)$ & $127( \pm 8)$ & $00: 30$ & No & Yes \\
$18 / 07$ & $8.9( \pm 0.7)$ & $135( \pm 9)$ & $00: 05$ & No & Yes \\
$20 / 07$ & $8.7( \pm 0.7)$ & $138( \pm 8)$ & $01: 00$ & No & Yes \\
$26 / 07$ & $12.0(\mathrm{~N} / \mathrm{A})$ & $63( \pm 12)$ & $00: 05$ & Yes & Yes \\
$29 / 07^{\mathrm{b}}$ & $9.1( \pm 0.1)$ & $100( \pm 8)$ & $00: 10$ & No & \\
& $7.7( \pm 0.3)$ & $225( \pm 7)$ & $00: 10$ & & Yes \\
$05 / 08$ & $9.1(\mathrm{~N} / \mathrm{A})$ & $61( \pm 10)$ & $0: 05$ & Yes & No \\
$13 / 08$ & $10.8(\mathrm{~N} / \mathrm{A})$ & $28( \pm 6)$ & $0: 05$ & Yes & \\
\hline
\end{tabular}

$\mathrm{N} / \mathrm{A}=$ not applicable (storm duration less than $5 \mathrm{~min}$ ).

Wind direction: North $=0^{\circ}$, positive clockwise. The last two columns indicate whether a given storm was considered for mass balance calculations based on wind direction.

a Mean \pm standard deviation.

b Multiple events on the same day. 

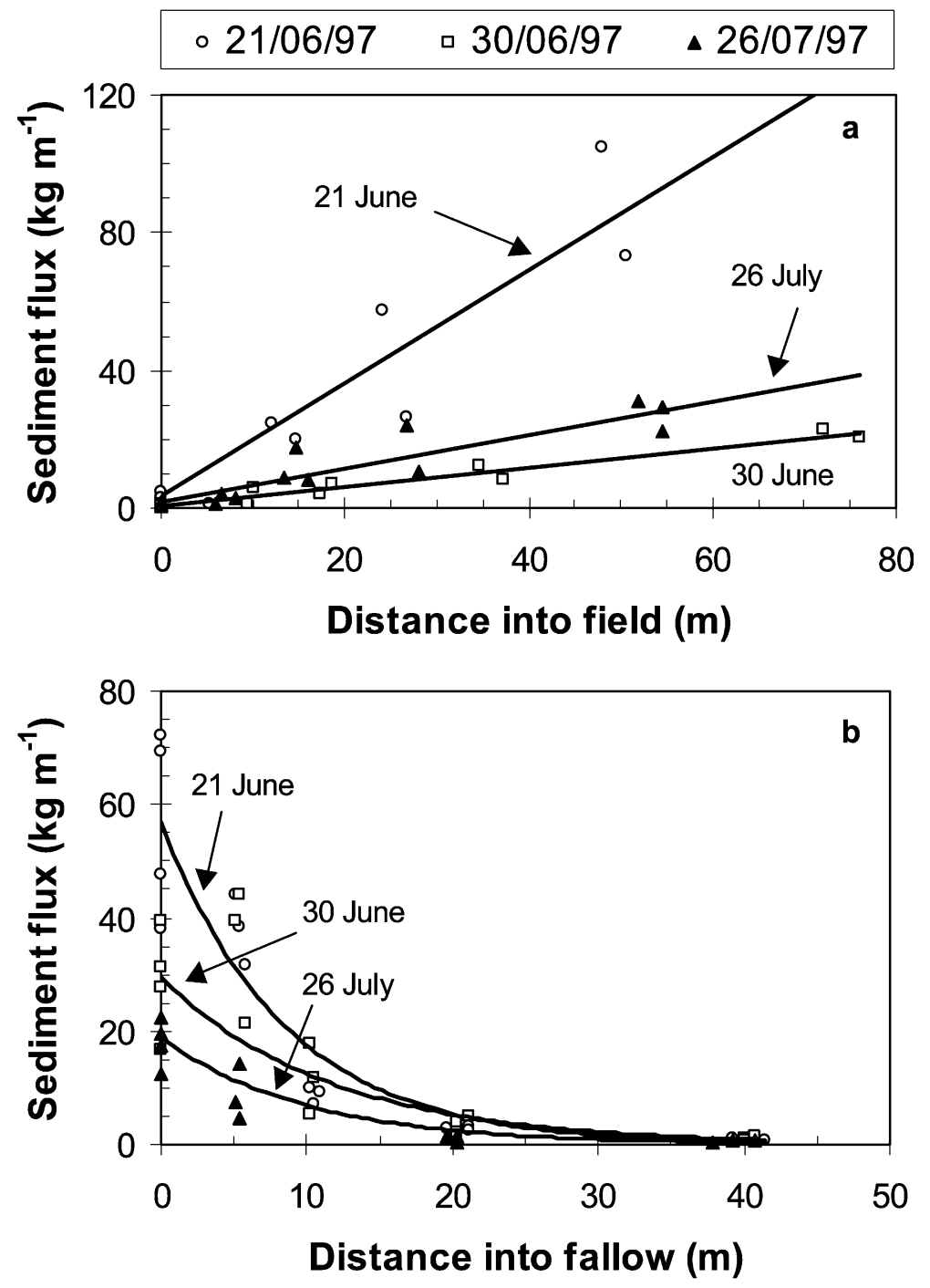

Fig. 2. Changes in eolian sediment flux with distance into a field (a) and into a bush fallow (b) for the three most erosive dust storms in 1997. Regression equations for the field and bush fallow are provided in Tables 2 and 3 , respectively.

the storm on 21 June when incoming fluxes averaged $3.8 \mathrm{~kg} \mathrm{~m}^{-1}$. Maximum measured sediment fluxes in the field reached $105 \mathrm{~kg} \mathrm{~m}^{-1}$ at $48 \mathrm{~m}$ from the boundary on 21 June (Fig. 2a). Virtually linear increases of sediment flux or mass flux density over sometimes considerable distances have been reported previously (Chepil, 1946; Fryrear and Saleh, 1996; Stout, 1990). The linearity reflects the fact that the transport capacity of the wind was never achieved over the distances under consideration in the present experiment (Fryrear et al., 1991; Stout, 1990). 
Table 2

Linear regression coefficients and correlation coefficient $\left(R^{2}\right)$ of sediment flux $\left(q ; \mathrm{kg} \mathrm{m}^{-1}\right)$ vs. distance $(x ; \mathrm{m})$ in the field, and calculated sediment balance $(-=$ loss, $+=$ gain $)$

\begin{tabular}{llllll}
\hline Date & \multicolumn{2}{l}{ Regression $q=q_{\text {in }}+\beta x$} & & $\begin{array}{l}\text { Mass balance } \\
\left(\mathrm{kg} \mathrm{m}^{-2}\right)\end{array}$ & $\begin{array}{l}\text { Distance } \\
(\mathrm{m})\end{array}$ \\
\cline { 2 - 5 } & $q_{\mathrm{in}}\left(\mathrm{kg} \mathrm{m}^{-1}\right)$ & $\beta\left(\mathrm{kg} \mathrm{m}^{-2}\right)$ & $R^{2}$ & & 51 \\
$21 / 06$ & 3.8 & 1.64 & 0.86 & -1.64 & 56 \\
$27 / 06$ & 0.02 & 0.14 & 0.80 & -0.14 & 76 \\
$30 / 06$ & 0.7 & 0.28 & 0.94 & -0.28 & 55 \\
$26 / 07$ & 1.6 & 0.48 & 0.81 & -0.48 & 54 \\
$05 / 08$ & 0.6 & 0.08 & 0.71 & -0.08 & 46 \\
$13 / 08$ & 0.4 & 0.20 & 0.87 & -0.20 & 5 \\
\hline
\end{tabular}

'Distance' refers to the distance into the field over which the mass balance applies, which is a function of wind direction.

\subsubsection{Bush fallow}

Sediment fluxes in the bush fallow decreased rapidly with distance (Fig. 2b). Sediment fluxes entering the bush fallow from the field ranged between 4.5 and $56.8 \mathrm{~kg} \mathrm{~m}^{-1}$ depending on the storm $\left(q_{\text {in }}\right.$; Table 3$)$. Measured fluxes always reached values $<1.1 \mathrm{~kg}$ $\mathrm{m}^{-1}$ within the first $40 \mathrm{~m}$ of the bush fallow.

The observed decrease of sediment flux vs. distance into the bush fallow could be reasonably described using an exponential decay function of the type:

$$
q=q_{\text {in }} \exp (-\alpha x)
$$

where $q\left[\mathrm{~kg} \mathrm{~m}^{-1}\right]$ is the sediment flux, $q_{\mathrm{in}}\left[\mathrm{kg} \mathrm{m}^{-1}\right]$ is the average measured sediment flux entering the bush fallow from the field, $x[\mathrm{~m}]$ is the distance into the bush fallow and $\alpha$ $\left[\mathrm{m}^{-1}\right]$ is a fitting parameter that reflects the trapping efficiency of the bush fallow

Table 3

Regression coefficients and correlation coefficient $\left(R^{2}\right)$ of the fitted constrained exponential function of sediment flux $\left(q ; \mathrm{kg} \mathrm{m}^{-1}\right)$ vs. distance $(x ; \mathrm{m})$ in the bush fallow, and calculated sediment balance $(-=\operatorname{loss},+=$ gain $)$

\begin{tabular}{llllll}
\hline Date & \multicolumn{2}{l}{ Regression $q=q_{\text {in }} \exp (\alpha x)$} & & $\begin{array}{l}\text { Mass balance } \\
\left(\mathrm{kg} \mathrm{m}^{-2}\right)\end{array}$ & $\begin{array}{l}\text { Distance } \\
(\mathrm{m})\end{array}$ \\
\cline { 2 - 5 } & $q_{\mathrm{in}}{ }^{\mathrm{a}}\left(\mathrm{kg} \mathrm{m}^{-1}\right)$ & $\alpha\left(\mathrm{m}^{-1}\right)$ & $R^{2}$ & & 41 \\
$21 / 06$ & 56.8 & -0.118 & 0.88 & 1.37 & 42 \\
$23 / 06$ & 30.3 & -0.086 & 0.94 & 0.70 & 40 \\
$27 / 06$ & 13.6 & -0.116 & 0.85 & 0.34 & 41 \\
$30 / 06$ & 29.4 & -0.086 & 0.88 & 0.70 & 47 \\
$07 / 07$ & 5.9 & -0.053 & 0.57 & 0.11 & 36 \\
$10 / 07$ & 25.7 & -0.125 & 0.92 & 0.70 & 33 \\
$18 / 07$ & 17.5 & -0.125 & 0.78 & 0.52 & 42 \\
$20 / 07$ & 20.8 & -0.130 & 0.79 & 0.49 & 41 \\
$26 / 07$ & 18.9 & -0.101 & 0.83 & 0.45 & 45 \\
$29 / 07$ & 9.4 & -0.074 & 0.35 & 0.20 & 41 \\
$05 / 08$ & 4.5 & -0.074 & 0.25 & 0.10 & \\
\hline
\end{tabular}

'Distance' refers to the distance into the bush fallow over which the mass balance applies, which is a function of wind direction.

${ }^{\text {a }} q_{\text {in }}$ was constrained to be equal to the average measured sediment flux entering the bush fallow $(n=5)$. 
vegetation. Because unconstrained fitting of Eq. (3) led to a systematic underestimation of measured fluxes at the field-bush fallow boundary, $q_{\text {in }}$ in Eq. (3) was constrained to be equal to the measured average sand flux of the five sand-traps located at the bush fallow boundary. In general, correlation coefficients of the constrained exponential function were high, except for the three weakest storms with $q_{\text {in }}<10 \mathrm{~kg} \mathrm{~m}^{-1}$ which were poorly fitted (Table 3). For those three storms, the exponential function tended to underestimate the actual decay rate.

The value of the coefficient $\alpha$ was to some extent dependent on the range of distances over which the experimental data were fitted, the maximum range varying from one event to another and being dictated by the relative orientation of the field boundary with respect to wind direction. In order to reduce the bias that could be introduced in the estimation of $\alpha$ as a result of this, the exponential function was fitted as much as possible over similar distances for all storms (32-47 $\mathrm{m}$ depending on the storm; Table 3). Using this procedure, $\alpha$ was approximately constant at $0.111 \pm 0.018 \mathrm{~m}^{-1}(n=8)$ for $10<q_{\text {in }}<57 \mathrm{~kg} \mathrm{~m}^{-1}$. For $q_{\text {in }}<10 \mathrm{~kg} \mathrm{~m}^{-1}$, the value of $\alpha$ tended to be lower at $0.067 \pm 0.012 \mathrm{~m}^{-1}(n=3)$. No consistent change in the value of $\alpha$ was observed over the period of observation.

The accumulation of windblown sediment at the downwind boundary between higher and lower erodibility surfaces is a well-known consequence of wind erosion (e.g., Larney et al., 1998). As windblown sediment is transported from a higher erodibility surface onto a lower erodibility surface, a transition zone exists where both the wind and windblown sediment profiles adjust to the new surface roughness conditions. The length of this transition zone ('adaptation length'; Van Dijk et al., 1999) is expected to depend on sediment influx, wind velocity as well as on soil and vegetation characteristics which may influence both the rate of decline and the equilibrium sediment flux rate. To the authors knowledge, no data has been published concerning the decline in sediment flux occurring in the transition zone between highly erodible cropland and low erodibility vegetated surfaces. However, Anderson (1988) reported an exponential decline in sediment transport at the lee of aeolian dunes. In their model of sediment transport across transversal dunes, Van Dijk et al. (1999) also assumed an exponential decay of the sediment transport rate in the transition zone.

The absence of seasonal effect on the value of $\alpha$ was somewhat surprising, since one would have expected the effect of the vegetation to increase during the course of the rainy season as bushes recovered their leaves and the grassy vegetation developed. However, in the present case, the part of the bush fallow that had been instrumented appeared to be very little browsed on by livestock. Even at the start of the rainy season, after a 9-month dry season, it presented a fairly dense litter and standing vegetation cover. Soil erodibility therefore probably remained very low throughout the observation period. The present data points to the effectiveness of bush fallow land at reducing wind erosion and at trapping incoming sediment, irrespective of the time of year.

Although the measured sediment fluxes originating from the bush fallow at the fallowfield boundary were not nil and the bush fallow would therefore not strictly qualify as 'non-erodible land', such fluxes remained low (Fig. 2a and Table 2). Sediment fluxes entering the field from the bush fallow constituted less than $6 \%$ of the sediment fluxes measured $80 \mathrm{~m}$ into the field along the transect for all storms except for the storm of 5 August for which it represented 14\%. The low erodibility of bush fallow land was also 
apparent from the low sediment fluxes measured $40 \mathrm{~m}$ into the bush fallow on the western side of the experimental field. The overall lower sediment fluxes measured $40 \mathrm{~m}$ into the western bush fallow compared to the fluxes originating from the bush fallow on the eastern side of the experimental field was probably due to the denser herbaceous vegetation cover and more homogeneous bushy vegetation observed on the western side than on the eastern side. For all practical purposes, however, undegraded bush fallow land can be considered 'non-erodible' in the 500-mm annual rainfall zone of western Niger.

\subsection{Sediment mass balance}

\subsubsection{Cultivated field}

Based on the slope of the linear regression of sediment flux vs. distance, erosion rates as high as $1.64 \mathrm{~kg} \mathrm{~m}^{-2}$ were calculated for a single day within the first $51 \mathrm{~m}$ of the field on 21 June 1997 (Table 2). This loss corresponds to approximately $1 \mathrm{~mm}$ of topsoil, assuming a bulk density of $1600 \mathrm{~kg} \mathrm{~m}^{-3}$.

The calculated soil losses reported in Table 2 can by no means be extended to the entire cultivated field since saltation sediment fluxes are expected to achieve a maximum steady level at some distance into the field (Fryrear et al., 1991; Stout, 1990; Fryrear and Saleh, 1996). In addition, because the notion of 'distance into the field' varies according to the relative orientation of the field boundaries with respect to wind direction during the dust storms, it is not appropriate to sum the calculated soil losses for individual events to arrive at a cumulative soil loss. Nevertheless, despite the fact that measurements were limited to a fairly narrow strip of land into a cultivated field, the present results provide clear indication of the potential magnitude of soil losses by wind erosion in conventionally managed fields. Although there are no data available concerning field scale soil losses by wind erosion under traditional management for Western Niger, the present figures are comparable in magnitude to those reported by Bielders et al. (2000) for $300 \mathrm{~m}^{2}$ unmulched experimental plots from a nearby on-farm trial over the period 1995-1997 as well as those reported by Sterk et al. (1996) for $40 \times 60 \mathrm{~m}^{2}$ plots from on-station measurements on similar soils in 1993.

\subsubsection{Bush fallow}

Based on the fitted constrained exponential regressions of sediment fluxes vs. distance into the bush fallow, sediment mass balance calculations were carried out (Table 3). A maximum average deposition rate of $1.37 \mathrm{~kg} \mathrm{~m}^{-2}$ was measured on 21 June within the first $41 \mathrm{~m}$ of the bush fallow land. The calculated average deposition rates reported in Table 3 are only indicative, however, since on average $89 \%$ of the sediment deposition actually occurred with the first $20 \mathrm{~m}$ of the bush fallow as a result of the exponential decay of sediment flux vs. distance $\left(\alpha=0.111 \mathrm{~m}^{-1}\right)$.

\subsection{Soil nutrient content}

\subsubsection{Cultivated field}

No significant trend in soil organic $\mathrm{C}$, total $\mathrm{N}$ and total $\mathrm{P}$, or in soil particle-size of the top $20 \mathrm{~mm}$ of the soil was apparent in the first $80 \mathrm{~m}$ of the field (Table 4). However, there 
Table 4

Changes in selected chemical properties and particle size of the topsoil $(0-0.02 \mathrm{~m})$ with distance into the field or bush fallow

\begin{tabular}{lllllll}
\hline & $\begin{array}{l}\text { C. org. } \\
(\%)\end{array}$ & $\begin{array}{l}\text { Total N } \\
\left(\mathrm{mg} \mathrm{kg}^{-1}\right)\end{array}$ & $\begin{array}{l}\text { Total P } \\
\left(\mathrm{mg} \mathrm{kg}^{-1}\right)\end{array}$ & $\begin{array}{l}\text { Sand, 50-2000 } \\
\left(\mathrm{g} \mathrm{kg}^{-1}\right)\end{array}$ & $\begin{array}{l}\text { Silt, 2-50 } \mu \mathrm{m} \\
\left(\mathrm{g} \mathrm{kg}^{-1}\right)\end{array}$ & $\begin{array}{l}\text { Clay, }<2 \mu \mathrm{m} \\
\left(\mathrm{g} \mathrm{kg}^{-1}\right)\end{array}$ \\
\hline Field & & & & & & 36 \\
$0-10 \mathrm{~m}$ & 0.18 & 151 & 57 & 943 & 22 & 28 \\
$30-40 \mathrm{~m}$ & 0.19 & 153 & 59 & 948 & 26 & 28 \\
$70-80 \mathrm{~m}$ & 0.19 & 149 & 57 & 946 & & 10 \\
& & & & & 20 & 14 \\
Bush fallow & & & 35 & 970 & 46 & 22 \\
$0-5 \mathrm{~m}$ & 0.14 & 116 & 46 & 931 & 5 & 24 \\
$5-10 \mathrm{~m}$ & 0.25 & 190 & 40 & 921 & 55 & \\
$10-20 \mathrm{~m}$ & 0.25 & 185 & 44 & 921 & & \\
$30-40 \mathrm{~m}$ & 0.21 & 174 & 44 & & & \\
\hline
\end{tabular}

appeared to be a steady decline in exchangeable $\mathrm{K}, \mathrm{Ca}$ and $\mathrm{Mg}$ content with distance into the field (Fig. 3).

The absence of a spatial trend in the soil's particle-size and organic C, N and P contents is consistent with the observed constancy of the erosion rate with distance over the first 80 $\mathrm{m}$ of the field. The observed decrease in exchangeable $\mathrm{K}, \mathrm{Ca}$ and $\mathrm{Mg}$ content into the field is unlikely to be related to redistribution of sediment by wind as one would expect any change in exchangeable cation content to be correlated with a change in SOM and/or clay content. The sum of exchangeable bases $(\mathrm{Na}, \mathrm{K}, \mathrm{Ca}, \mathrm{Mg})$ decreased from $0.85 \mathrm{cmol}_{+} \mathrm{kg}^{-1}$ in the first $10 \mathrm{~m}$ of the field to $0.55 \mathrm{cmol}_{+} \mathrm{kg}^{-1}$ at a distance of $70-80 \mathrm{~m}$, which could

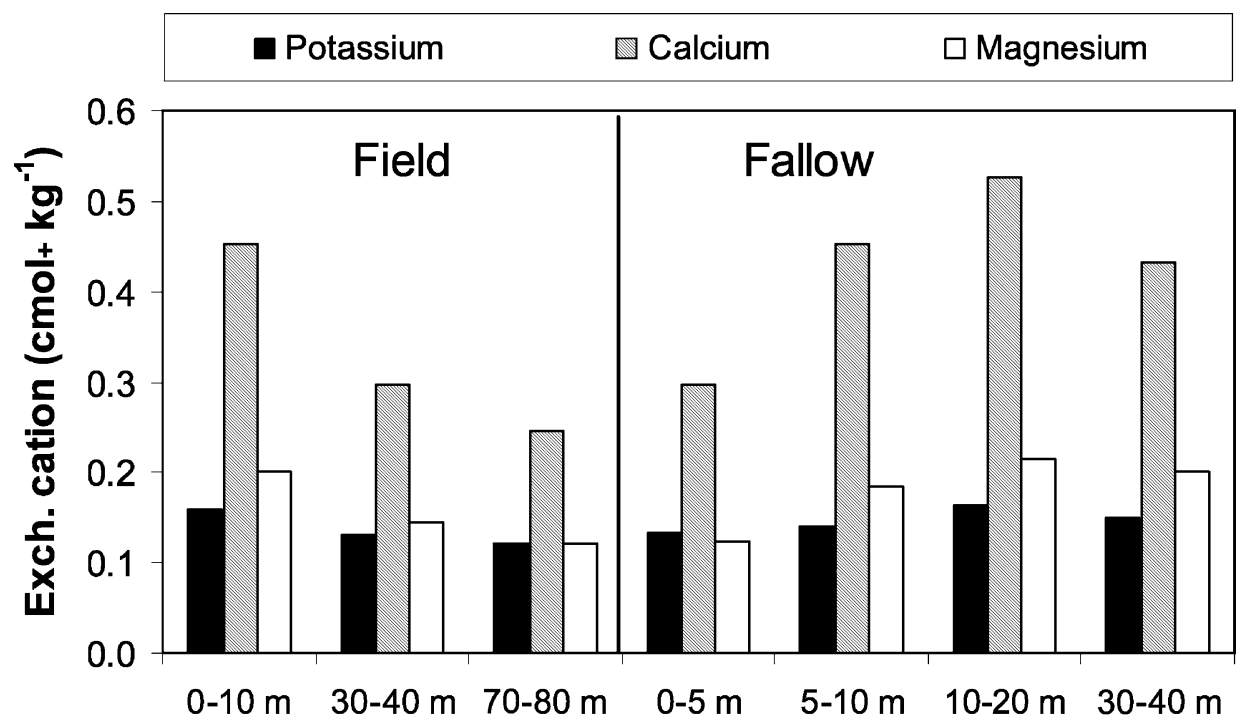

Fig. 3. Changes in exchangeable $\mathrm{K}, \mathrm{Ca}$ and $\mathrm{Mg}$ content in the topsoil $(0-0.02 \mathrm{~m})$ as a function of distance into the field or into the bush fallow. 
result from a decrease in either the CEC or the base saturation ratio. Given the near constant clay and OC content and that the increase in clay content was partly compensated for by a decrease in OC (Table 4), it is likely that the observed trend in exchangeable cation content resulted predominantly from a decrease in the base saturation ratio, which could be related to variability in crop growth or soil management practices.

\subsubsection{Bush fallow}

Total silt + clay content increased over the first $20 \mathrm{~m}$ into the bush fallow (Table 4). A corresponding increase in organic $\mathrm{C}$, total $\mathrm{N}$ and $\mathrm{P}$ (Table 4), as well as in exchangeable $\mathrm{K}$, $\mathrm{Ca}$ and $\mathrm{Mg}$ content (Fig. 3) was observed within the first 10 to $20 \mathrm{~m}$. Although they studied a much finer textured soil, Larney et al. (1998) also reported increases in soil OC and nutrient content $(0-0.025 \mathrm{~m}$ depth) in the first $45 \mathrm{~m}$ of a non-erodible stubble field that served as a depositional area for windblown sediment originating from a leeward cultivated field.

The observed trend in fine particle content $(<50 \mu \mathrm{m})$, organic $\mathrm{C}$ and soil nutrient content is believed to largely reflect the spatial trend in sediment deposition in the bush fallow. Near the field border, the bush fallow trapped considerable amounts of sediment eroded from the field (Fig. 2). Because the soil in the field can, on average, be expected to have lower nutrient and organic carbon content than the bush fallow as a result of continuous cultivation, and because sediment transport and deposition in the bush fallow is likely to be selective with respect to particle size, one expects the topsoil of the bush fallow near the field boundary to be diluted over time by sediment coarser in texture and lower in nutrient content. Further into the bush fallow finer sediment richer in OC is expected to deposit, adding to already more fertile soil. The observed changes in exchangeable base contents (Fig. 3) are positively correlated with clay and OC content, these two properties explaining $49.3 \%$ of the observed variance in total exchangeable bases content in the bush fallow $(n=4)$.

\subsection{Nutrient fluxes}

\subsubsection{Cultivated field}

In the field, there were substantial differences in nutrient content of trapped sediment between the three storms for all elements except P (not shown). Nutrient contents in the sediment were generally highest on 30 June and lowest on 26 July.

Total nutrient content in the sediment samples generally declined with distance into the field at both measurement heights on 21 June (Fig. 4). The observed decrease was sharpest in the first $25 \mathrm{~m}$ ( $=40 \mathrm{~m}$ along the transect). Similar trends were observed for both heights.

Whereas total $\mathrm{P}, \mathrm{K}$ and $\mathrm{Mg}$ declined in roughly equal proportion over the first $80 \mathrm{~m}$ of the field $(33-42 \%)$ at $0.1 \mathrm{~m}$ height on 21 June, $\mathrm{N}$ declined by $64 \%$ and $\mathrm{Ca}$ declined by $82 \%$. Similar trends in nutrient decline with distance were also observed on 26 July at 0.1 $\mathrm{m}$ height, though the relative decline in nutrient content with distance was generally less than on 21 June. Because sediment sample sizes did not permit some or all of the chemical analyses to be performed, it could not be verified whether these trends held on 30 June at $0.1 \mathrm{~m}$, and at $0.35 \mathrm{~m}$ on 30 June and 26 July.

Nutrient content at $0.35 \mathrm{~m}$ height was always higher than at $0.1 \mathrm{~m}$ above ground (Table 5). This is commonly observed and reflects a relative enrichment in clay and/or organic 


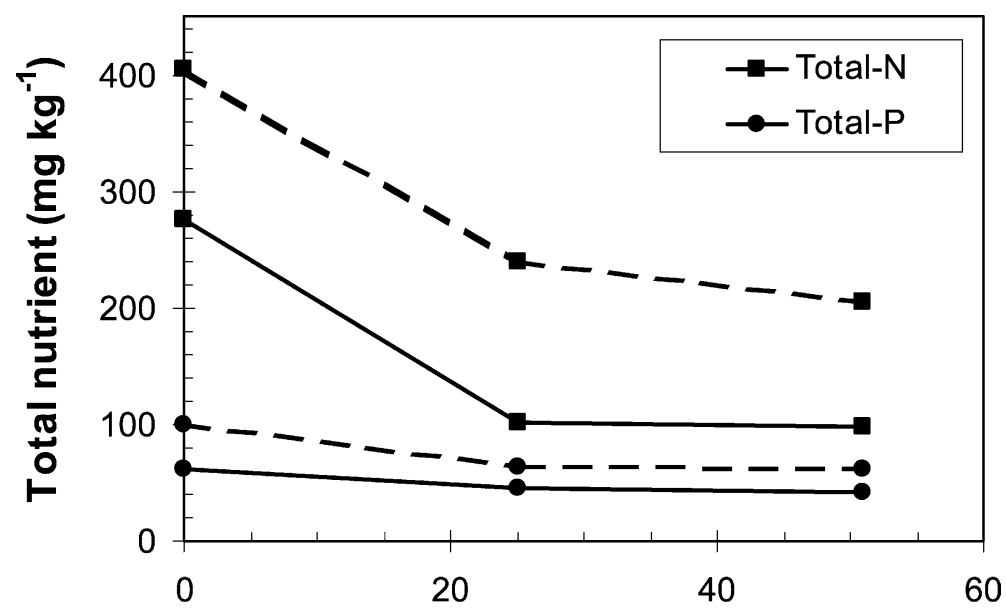

Distance into field (m)

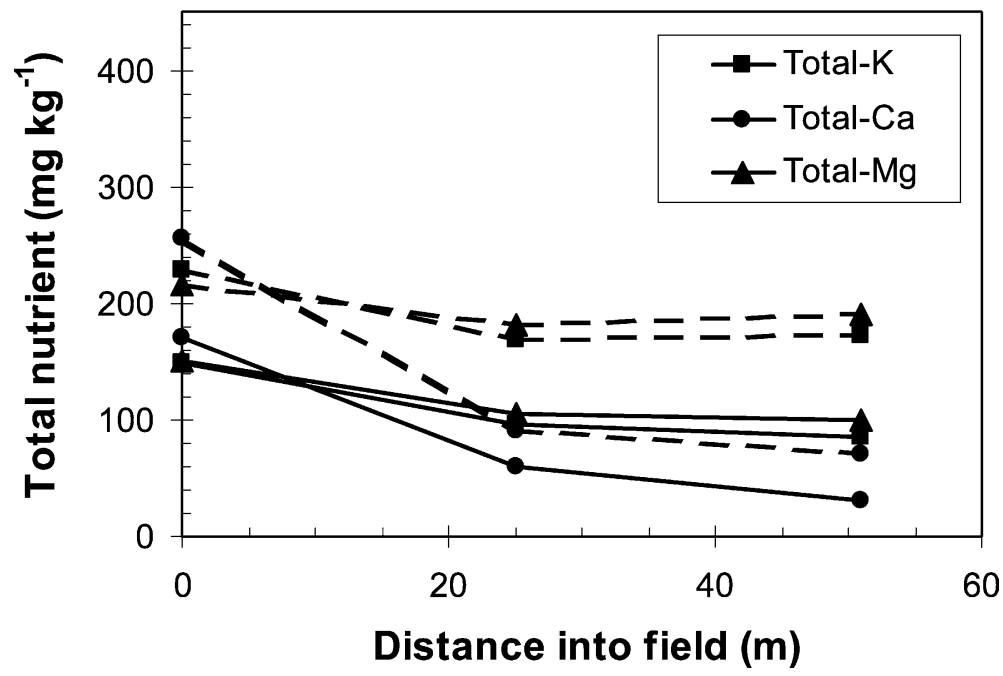

Fig. 4. Changes in total $\mathrm{N}, \mathrm{P}, \mathrm{K}, \mathrm{Ca}$ and $\mathrm{Mg}$ content of windblown sediment collected in the field $0.1 \mathrm{~m}$ (continuous line) and $0.35 \mathrm{~m}$ (dashed line) above ground on 21 June 1997.

matter with height (Zobeck and Fryrear, 1986; Michels et al., 1995; Sterk et al., 1996). A nutrient enrichment ratio (NER) can be defined as:

$$
\mathrm{NER}=\frac{C_{35}}{C_{10}}
$$

where $C_{10}$ and $C_{35}$ are the nutrient contents of the sediment collected at 0.1 and $0.35 \mathrm{~m}$ above ground, respectively. 
Table 5

Total elemental content of sediment samples collected on 21 June 1997 in sand-traps located 0.1 and $0.35 \mathrm{~m}$ above ground 0 and $80 \mathrm{~m}$ into the field or 0 and $40 \mathrm{~m}$ into the bush fallow, and nutrient enrichment ratio between samples from 0.35 and $0.1 \mathrm{~m}$ height

\begin{tabular}{|c|c|c|c|c|c|c|}
\hline & \multicolumn{3}{|c|}{ Field or fallow boundary } & \multicolumn{3}{|c|}{$80 \mathrm{~m}$ into field or $40 \mathrm{~m}$ into fallow ${ }^{\mathrm{a}}$} \\
\hline & \multicolumn{2}{|l|}{ Height } & \multirow{2}{*}{$\begin{array}{l}\text { Nutrient } \\
\text { enrichment } \\
\text { ratio }\end{array}$} & \multicolumn{2}{|l|}{ Height } & \multirow{2}{*}{$\begin{array}{l}\text { Nutrient } \\
\text { enrichment } \\
\text { ratio }\end{array}$} \\
\hline & $\begin{array}{l}0.1 \mathrm{~m} \\
\left(\mathrm{mg} \mathrm{kg}^{-1}\right)\end{array}$ & $\begin{array}{l}0.35 \mathrm{~m} \\
\left(\mathrm{mg} \mathrm{kg}^{-1}\right)\end{array}$ & & $\begin{array}{l}0.1 \mathrm{~m} \\
\left(\mathrm{mg} \mathrm{kg}^{-1}\right)\end{array}$ & $\begin{array}{l}0.35 \mathrm{~m} \\
\left(\mathrm{mg} \mathrm{kg}^{-1}\right)\end{array}$ & \\
\hline \multicolumn{7}{|c|}{ Field } \\
\hline $\mathrm{N}$ & 276 & 404 & 1.46 & 98 & 204 & 2.08 \\
\hline $\mathrm{P}$ & 62 & 99 & 1.59 & 42 & 62 & 1.48 \\
\hline K & 149 & 228 & 1.53 & 86 & 172 & 2.00 \\
\hline $\mathrm{Ca}$ & 170 & 255 & 1.50 & 30 & 70 & 2.33 \\
\hline $\mathrm{Mg}$ & 150 & 216 & 1.44 & 99 & 191 & 1.93 \\
\hline \multicolumn{7}{|c|}{ Bush fallow } \\
\hline $\mathrm{N}$ & 110 & 300 & 2.73 & n.d. ${ }^{\mathrm{b}}$ & n.d. ${ }^{\mathrm{b}}$ & n.d. ${ }^{\mathrm{b}}$ \\
\hline $\mathrm{P}$ & 28 & 48 & 1.71 & 63 & 67 & 1.07 \\
\hline $\mathrm{K}$ & 63 & 214 & 3.40 & 207 & 228 & 1.10 \\
\hline $\mathrm{Ca}$ & 105 & 170 & 1.62 & 250 & 270 & 1.08 \\
\hline $\mathrm{Mg}$ & 94 & 199 & 2.12 & 212 & 224 & 1.06 \\
\hline
\end{tabular}

The NER varied with distance into the field. This enrichment ratio ranged between 1.44 and 1.59 at the field boundary for all elements except for P on 21 June (Table 5). Eighty $\mathrm{m}$ into the field it increased to values comprised between 1.93 and 2.33. For P, a slight decrease was observed from 1.59 to 1.48 over the first $80 \mathrm{~m}$. With few exceptions, the NER $80 \mathrm{~m}$ into the field was generally lower on 30 June and 26 July compared to 21 June (not shown). Insufficient sample size did not permit chemical analysis of $0.35 \mathrm{~m}$ height sediment samples at the field boundary on 30 June and 26 July.

The rapid decline in total nutrient content in the field shown in Fig. 4 is what one would expect from a dilution process given that the sediment entrained from the bush fallow had a higher nutrient content than the material that could be entrained from the field. Because the mass of sediment leaving the bush fallow was small compared to the mass of sediment entrained from the field (e.g., Fig. 2), the dilution occurred very fast and the sediment rapidly reached a near constant nutrient content that corresponds to an equilibrium with the field soil.

The same dilution process can also explain the observed increase in the NER as one proceeds from the bush fallow boundary into the field. Indeed, sediment fluxes increase proportionally more rapidly nearer to the surface and the dilution process is therefore stronger at $0.1 \mathrm{~m}$ height than at $0.35 \mathrm{~m}$ height. On $21 \mathrm{June}$, for instance, the ratio of mass density fluxes at 0.35 - and $0.1-\mathrm{m}$ height was $28 \%$ on average at the bush fallowfield boundary and 12\% $80 \mathrm{~m}$ into the field (not shown). A similar trend in mass flux density with distance into an eroding field was also reported, for instance, by Stout and Zobeck (1996). The reason why in the present experiment the enrichment ratio for $\mathrm{P}$ decreased whereas it increased for the other nutrients remains unclear. However, a lower 
enrichment ratio for $\mathrm{P}$ than for $\mathrm{K}$ and $\mathrm{N}$ was also reported by Sterk et al. (1996) for similar soils.

\subsubsection{Bush fallow}

In the bush fallow, there were also marked differences in nutrient content between the three storms for all elements except $\mathrm{P}$ (not shown). Again, nutrient contents were generally highest on 30 June and lowest on 26 July. A general trend of increasing nutrient content with distance into the bush fallow was observed on 21 June (Fig. 5) and 30 June (not
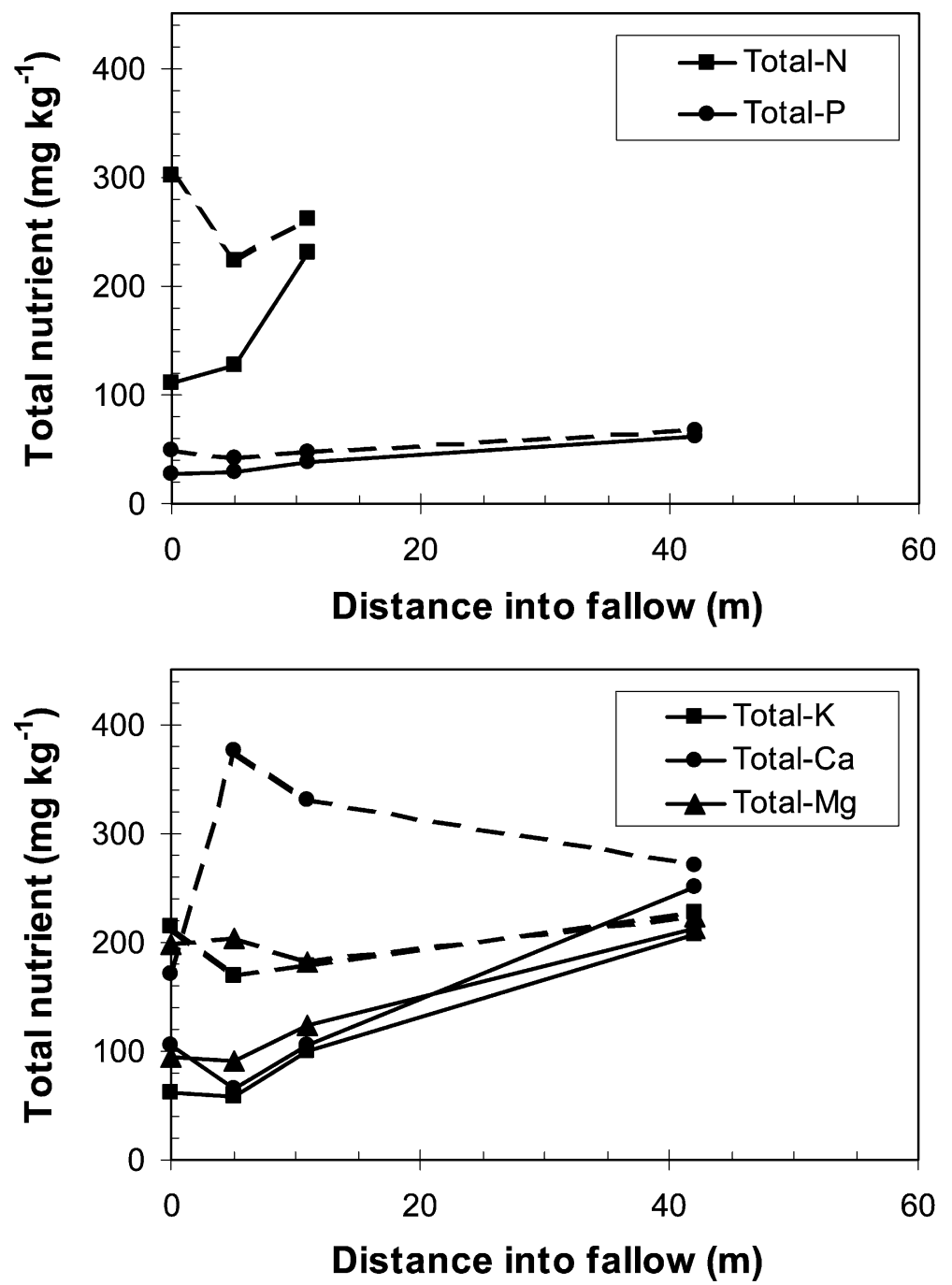

Fig. 5. Changes in total $\mathrm{N}, \mathrm{P}, \mathrm{K}, \mathrm{Ca}$ and $\mathrm{Mg}$ content of windblown sediment collected in the bush fallow $0.1 \mathrm{~m}$ (continuous line) and $0.35 \mathrm{~m}$ (dashed line) above ground on 21 June 1997. 
shown) for all elements at both heights, except for $\mathrm{Ca}$ at $0.35 \mathrm{~m}$ above ground (Fig. 5). The trend for total $\mathrm{N}$ could not be confirmed because of insufficient sample size $40 \mathrm{~m}$ into the bush fallow. Insufficient sample sizes also did not permit to confirm these trends on 26 July. On 21 June, with the exception of N, nutrient contents increased by a factor of 2.0 3.3 over a distance of $40 \mathrm{~m}$. N showed a much more rapid initial rise than other nutrients in the first $10 \mathrm{~m}$ of the bush fallow at $0.1 \mathrm{~m}$ height on both 21 June (Fig. 5) and 30 June (not shown), but lack of data due to insufficient sample sizes did not permit to confirm this trend beyond $20 \mathrm{~m}$.

As for the field, nutrient contents were higher at $0.35 \mathrm{~m}$ above ground compared to 0.1 $\mathrm{m}$ height (Table 5) but, based on the available data from 20 and 30 June, there was a general tendency for the nutrient content values at 0.1 and $0.35 \mathrm{~m}$ to converge $40 \mathrm{~m}$ into the bush fallow (Table 5 and Fig. 5). The NER at the fallow boundary ranged from 1.6 for $\mathrm{Ca}$ to 3.4 for $\mathrm{K}$, and decreased to $1.06-1.10$ for all elements $40 \mathrm{~m}$ into the bush fallow on 21 June (Table 5). As for the field measurements, and with few exceptions, the NER at the bush fallow boundary were generally lower on 30 June and 26 July compared to 21 June. Insufficient sample size did not allow for chemical analysis of $0.35 \mathrm{~m}$ height sediment samples $40 \mathrm{~m}$ into the bush fallow on 30 June and 26 July.

The tendency for the NER to reach values near unity $40 \mathrm{~m}$ into the bush fallow is indicative of the evolution of the windblown sediment towards a near constant composition of the sediment with height in terms of particle size and OC content. This evolution is reflected in the ratio of mass flux densities measured at 0.35 and $0.1 \mathrm{~m}$ above ground. On 21 June, for instance, this ratio reached an average value of $79 \% 40 \mathrm{~m}$ into the bush fallow, whereas its value was $9 \%$ at the bush fallow boundary.

The NER $40 \mathrm{~m}$ into the western bush fallow were consistently lower than those observed at the bush fallow boundary on the eastern side of the cultivated field. The observed difference can probably be attributed to the greater erodibility of the eastern bush fallow. This is supported by the higher soil fluxes measured in the eastern bush fallow compared to the western bush fallow. On average over all storms, fluxes leaving the eastern bush fallow were 3.5 times higher than the fluxes measured $40 \mathrm{~m}$ into the western bush fallow, despite the fact that the fetch in the eastern bush fallow was much greater than in the western bush fallow. This greater erodibility must have resulted in higher fluxes of coarse, nutrient-poor sediment close to the ground in the eastern bush fallow, and therefore in a higher enrichment ratio as compared to the western bush fallow.

\subsection{Nutrient mass balance}

Nutrient balances were calculated between $0-40$ and $40-80 \mathrm{~m}$ into the field, and between $0-10$ and $10-40 \mathrm{~m}$ into the western bush fallow. These nutrient balance calculations require, evidently, sediment nutrient content measurements $0 \mathrm{~m}$ into the field and $40 \mathrm{~m}$ into the bush fallow. However, as mentioned earlier, sediment sample sizes at these two locations on 30 June and 26 July were generally insufficient to permit soil chemical analyses. On those two dates, nutrient fluxes $0 \mathrm{~m}$ into the field were therefore estimated by assuming that this flux was equal to $15 \%$ of the nutrient flux measured $80 \mathrm{~m}$ into the field. This assumption is based on the observation that the average ratio of nutrient fluxes at 0 and $80 \mathrm{~m}$ into the field was equal to $13 \%$ on 21 June for all elements 
(range $7-27 \%$ ). The use of a ratio of $15 \%$ provided a conservative estimate of nutrient flux at the eastern field-bush fallow boundary for all elements except $\mathrm{Ca}$. For the western bush fallow, the mass balance was estimated similarly by assuming that the nutrient flux $40 \mathrm{~m}$ into the bush fallow corresponded to $5 \%$ of the nutrient flux entering the bush fallow from the field. This assumption is based on the observation that the average ratio of nutrient fluxes at 0 and $40 \mathrm{~m}$ into the bush fallow on 21 June was equal to $5 \%$ for all elements (range 4.6-6.6\%).

\subsubsection{Cultivated field}

Based on the above assumptions, highest nutrient losses in the field were observed on 21 June, which also corresponded to the highest soil losses (Table 6). On that date, nutrient losses ranged from $34 \mathrm{mg} \mathrm{m}^{-2}$ for Ca to $143 \mathrm{mg} \mathrm{m}^{-2}$ for $\mathrm{Mg}$. For $\mathrm{N}, \mathrm{P}, \mathrm{K}$ and $\mathrm{Mg}$, nutrient losses were greater between 25 and $51 \mathrm{~m}$ into the field than between 0 and $25 \mathrm{~m}$, mostly as a result of slightly larger soil losses between 25 and $51 \mathrm{~m}$ (Table 6). For Ca, the opposite was observed as a result of the large drop in Ca content between 25 and $51 \mathrm{~m}$ (Fig. 4). For the two other storms, nutrient losses never exceeded $42 \mathrm{mg} \mathrm{m}^{-2}$ for any single nutrient (Table 6).

Table 6

Sediment and nutrient mass balances for the field and bush fallow for the three major dust storms of 1997 ( $-=$ loss, $+=$ gain $)$

\begin{tabular}{|c|c|c|c|c|c|c|c|}
\hline \multirow[t]{2}{*}{ Date } & \multirow{2}{*}{$\begin{array}{l}\text { Distance } \\
(\mathrm{m})\end{array}$} & \multicolumn{6}{|c|}{ Mass balance } \\
\hline & & $\begin{array}{l}\text { Sediment } \\
\left(\mathrm{kg} \mathrm{m}^{-2}\right)\end{array}$ & $\begin{array}{l}\mathrm{N} \\
\left(\mathrm{mg} \mathrm{m}^{-2}\right)\end{array}$ & $\begin{array}{l}\mathrm{P} \\
\left(\mathrm{mg} \mathrm{m}^{-2}\right)\end{array}$ & $\begin{array}{l}\mathrm{K} \\
\left(\mathrm{mg} \mathrm{m}^{-2}\right)\end{array}$ & $\begin{array}{l}\mathrm{Ca} \\
\left(\mathrm{mg} \mathrm{m}^{-2}\right)\end{array}$ & $\begin{array}{l}\mathrm{Mg} \\
\left(\mathrm{mg} \mathrm{m}^{-2}\right)\end{array}$ \\
\hline \multicolumn{8}{|l|}{ Field } \\
\hline \multirow[t]{3}{*}{$21 / 06$} & $0-25$ & -1.51 & -109 & -59 & -118 & -62 & -133 \\
\hline & $25-51$ & -1.96 & -163 & -65 & -128 & -5 & -153 \\
\hline & $0-51$ & -1.64 & -135 & -62 & -123 & -34 & -143 \\
\hline \multirow[t]{3}{*}{$30 / 06$} & $0-36$ & -0.27 & n.d. ${ }^{\mathrm{a}}$ & -9 & -21 & -14 & -22 \\
\hline & $36-76$ & -0.29 & n.d. ${ }^{\mathrm{a}}$ & -13 & -41 & -23 & -38 \\
\hline & $0-76$ & -0.28 & -35 & -11 & -31 & -18 & -31 \\
\hline \multirow[t]{3}{*}{$26 / 07$} & $0-28$ & -0.49 & -36 & -16 & -20 & -7 & -30 \\
\hline & $28-55$ & -0.48 & -37 & -23 & -36 & -9 & -42 \\
\hline & $0-55$ & -0.48 & -36 & -20 & -28 & -8 & -36 \\
\hline \multicolumn{8}{|c|}{ Bush fallow } \\
\hline \multirow[t]{3}{*}{$21 / 06$} & $0-11$ & 4.56 & 305 & 92 & 198 & 355 & 310 \\
\hline & $11-42$ & 0.27 & 61 & 9 & 27 & 37 & 32 \\
\hline & $0-42$ & 1.37 & 126 & 31 & 72 & 121 & 106 \\
\hline \multirow[t]{3}{*}{$30 / 06$} & $0-10$ & 1.72 & 196 & 33 & 113 & 200 & 122 \\
\hline & $10-41$ & 0.35 & 99 & 13 & 39 & 30 & 44 \\
\hline & $0-41$ & 0.70 & 124 & 18 & 58 & 73 & 64 \\
\hline \multirow[t]{3}{*}{$26 / 07$} & $0-11$ & n.d. ${ }^{b}$ & - & - & - & - & - \\
\hline & $11-41$ & n.d. ${ }^{b}$ & - & - & - & - & - \\
\hline & $0-41$ & 0.45 & 34 & 10 & 17 & 9 & 21 \\
\hline
\end{tabular}

The mass balances are calculated over a certain distance into the field or bush fallow.

${ }^{a}$ Missing nutrient content data because of insufficient sample size.

b Missing soil flux data $11 \mathrm{~m}$ into the bush fallow. 


\subsubsection{Bush fallow}

In the bush fallow, the nutrient deposition rate on 21 June was 5 to 10 times higher in the first $11 \mathrm{~m}$ than between 11 and $42 \mathrm{~m}$ (Table 6). Average deposition rates in the first 42 $\mathrm{m}$ ranged from $30 \mathrm{mg} \mathrm{m}^{-2}$ for $\mathrm{P}$ to $130 \mathrm{mg} \mathrm{m}^{-2}$ for N. Similar deposition rates were calculated on 30 June for $\mathrm{N}, \mathrm{P}$ and $\mathrm{K}$, but were 55 to $60 \%$ lower for $\mathrm{Ca}$ and $\mathrm{Mg}$. On 26 July, deposition rates never exceeded $30 \mathrm{mg} \mathrm{m}^{-2}$.

Despite the large measured soil losses, nutrient losses remained comparatively low as a result of the low nutrient content of the native soils. Nevertheless, nutrient losses during the storm of 21 June alone represents between $3 \%(\mathrm{~K})$ and $17 \%(\mathrm{P})$ of the nutrients taken up in the total dry matter by a millet crop yielding 500 grain $\mathrm{kg} \mathrm{ha}^{-1}$, based on a harvest index of 0.30 (grain yield/straw yield) and N, P and $\mathrm{K}$ contents of respectively $0.8 \%$, $0.12 \%$, and $2.4 \%$ for straw and $2.1 \%, 0.32 \%$, and $0.40 \%$ for grain (Buerkert, 1995 ; Hafner, 1992). A grain yield of $500 \mathrm{~kg} \mathrm{ha}^{-1}$ can be considered representative of an average yield for the area in the absence of fertilizer inputs. Although low in absolute terms, nutrient losses by wind erosion are therefore by no means negligible, particularly in the case of $\mathrm{P}$.

The nutrient losses reported here are comparatively lower, on a per unit soil loss basis, than those reported by Sterk et al. (1996). This is due primarily to the lower fertility of the present experimental site compared to the site studied by Sterk et al. (1996). Total P and N content in the top $0.02 \mathrm{~m}$ of the soil are indeed roughly 3 times higher at the latter site than at the present site (total $\mathrm{K}$ content of the topsoil was not measured in the present experiment).

Because sediment and nutrient fluxes above $0.35 \mathrm{~m}$ height were not taken into account, the total sediment and nutrient fluxes reported in the present study may therefore be underestimated to some extent. The underestimation of the total mass flux is small, however, in the cultivated field. For instance, for the storm of 21 June 1997, the total flux between 0 and $0.35 \mathrm{~m}$ height in the field is estimated to represent on average $91 \%( \pm 8 \%)$ of the total flux that would be expected between 0 and $1 \mathrm{~m}$ height on the basis of the fitted power functions. Although some additional material may be transported in suspension above $1 \mathrm{~m}$ height, the contribution of this suspended sediment to the total sediment mass can be considered negligible because of the very rapid decrease of the sediment mass flux density with height. Fryrear et al. (1991) also concluded for their soils that most sediment is transported below $0.3 \mathrm{~m}$ height. In the fallow, where the mass flux density decreased less rapidly with height, restricting the measurements to $0.35 \mathrm{~m}$ height may have led to an underestimation by as much as $60 \%$ for the storm of 21 June compared to the expected flux between 0 and $1 \mathrm{~m}$ height. However, the total mass flux in the bush fallow was generally at least one order of magnitude lower than in the field and the underestimation is therefore of little consequence for the sediment mass balance calculations.

Because nutrient concentration tends to increase with height, the underestimation of the nutrient fluxes resulting from the restriction on the maximum height of measurement is larger than for the sediment fluxes. The underestimation is of the order of $13 \%( \pm 5 \%) 80$ $\mathrm{m}$ into the field and 59\% ( $\pm 1 \%$ ) $40 \mathrm{~m}$ into the fallow. For the cultivated field, it appears again that the underestimation of the nutrient fluxes in the field is relatively small. Even though the underestimation is larger in the fallow, it is again of limited impact for the nutrient balance calculations because the nutrient fluxes $40 \mathrm{~m}$ into the fallow are about one order of magnitude lower than the nutrient fluxes entering the fallow. 


\section{Conclusions}

Based on the measurements of windblown sediment fluxes in traditionally managed land in western Niger, it appears that wind erosion may result in considerable soil losses. However, the measured soil losses apply only over a limited length into the cultivated fields. The associated nutrient losses are comparatively low in absolute terms, but such losses are by no means negligible when compared to the average annual nutrient uptake of a millet crop. Wind erosion may therefore substantially increase the rate of soil fertility decline on the inherently poor sandy eolian soils of western Niger.

Natural bush fallow vegetation constitutes an efficient means of reducing wind erosion as it effectively traps incoming saltation sediment from adjacent, more erodible fields. Under the present land-use conditions wind erosion therefore results largely in short distance transport of sediment between cultivated fields and adjacent bush fallow land. In areas with little or no bush fallow vegetation, grass strips approx. $20 \mathrm{~m}$ in width oriented perpendicular to the dominant wind direction could provide an effective means of reducing the long range transport of windblown saltating sediment. A lower trapping efficiency is to be expected, however, for finer suspended sediment.

Because wind erosion at the experimental site results mostly in a local redistribution of sediment between adjacent land units, the present results do not appear to support previous estimates of regional scale soil erosion rates in excess of $48 \mathrm{Mg} \mathrm{ha}^{-1}$ year ${ }^{-1}$ under present land-use conditions (Chappell et al., 1998). The present results, however, need to be confirmed through longer term, field scale measurements of soil and nutrient fluxes for the major land-use types of the Nigerien Sahel.

\section{Acknowledgements}

This research was funded in part through the Netherlands Directorate General for International Cooperation (DGIS). The assistance of the Soil and Water Management team of ICRISAT, Mr. Siaka Maharou and Mr. B. Mahamadou is gratefully acknowledged.

\section{References}

Anderson, R.A., 1988. The pattern of rainfall deposition in the lee of aeolian dunes. Sedimentology 35, $175-188$.

Bielders, C.L., Michels, K., Rajot, J.-L., 2000. On-farm evaluation of ridging and residue management practices to reduce wind erosion in Niger. Soil Sci. Soc. Am. J. 64, 1776-1785.

Bielders, C.L., Alvey, S., Cronyn, N., 2001. Wind erosion: the perspective of grass-roots communities in the Sahel. Land Degrad. Dev. 12, 57-70.

Bremmner, J.M., Mulvaney, C.S., 1982. Nitrogen total. In: Page, A.L., Miller, R.H., Keeney, D.R. (Eds.), Methods of Soil Analysis. Part II. Chemical and Microbiological Properties. ASA and SSSA, Madison, WI, USA, pp. 595-622.

Buerkert, A., 1995. Effects of crop residues, phosphorus, and spatial variability on yield and nutrient uptake of pearl millet in southwest Niger. PhD dissertation, University of Hohenheim, Stuttgart, Germany, pp. 272.

Buerkert, A., Lamers, J.P.A., 1999. Soil erosion and deposition effects on surface characteristics and pearl millet growth in the West African Sahel. Plant Soil 215, 239-253. 
Chappell, A., 1996. Modelling the spatial variation of processes in the redistribution of soil: digital terrain model and Cs-137 in southwest Niger. Geomorphology 17, 249-261.

Chappell, A., Warren, A., Taylor, N., Charlton, M., 1998. Soil flux (loss and gain) in southwestern Niger and its agricultural impact. Land Degrad. Dev. 9, 295-310.

Chepil, W.S., 1946. Dynamics of wind erosion: V. Cumulative intensity of soil drifting across eroding fields. Soil Sci. 61, 257-263.

Drees, L.R., Manu, A., Wilding, L.P., 1993. Characteristics of aeolian dusts in Niger, West Africa. Geoderma 59, $213-233$.

Fryrear, D.W., 1986. A field dust sampler. J. Soil Water Conserv. 41, 117-120.

Fryrear, D.W., Saleh, A., 1996. Wind erosion: field length. Soil Sci. 161, 398-404.

Fryrear, D.W., Stout, J.E., Hagen, L.J., Vories, E.D., 1991. Wind erosion: field measurement and analysis. Trans. ASAE 34, 155-160.

Gavaud, M., 1977. Les grands traits de la pédogenèse au Niger méridional. Travaux et Documents de l'ORSTOM $\mathrm{N}^{\circ} 78$.

Gee, G.W., Bauder, J.W., 1986. Particle-size analysis. In: Klute, A. (Ed.), Methods of Soil Analysis. Part I. Physical and Mineralogical Methods. ASA and SSSA, Madison, WI, USA, pp. 383-411.

Hafner, H., 1992. Effect of organic and inorganic fertilizer application on growth and mineral nutrient uptake of pearl millet and groundnut in an acid sandy soil of Niger. PhD dissertation, University of Hohenheim, Stuttgart, Germany, pp. 121.

Herrmann, L., 1996. Staubdeposition auf Böden West-Afrikas. PhD dissertation, University of Hohenheim, Stuttgart, Germany, pp. 239.

Houba, V.J.G., van der Lee, J.J., Novozamski, I., 1995. Soil Analysis Procedures, Other Procedures Dept. Soil Sci. and Plant Nutr., Wageningen University, Wageningen, The Netherlands.

Larney, F.J., Bullock, M.S., Janzen, H.H., Ellert, B.H., Olson, C.S., 1998. Wind erosion effects on nutrient redistribution and soil productivity. J. Soil Water Conserv. 53, 133-140.

Leys, J., McTainsh, G., 1994. Soil loss and nutrient decline by wind erosion-cause for concern. Aust. J. Soil Water Conserv. 7, 30-35.

Mainguet, M., 1998. Wind erosion in Africa, a neglected creeping or catastrophic process of land degradation: suggestions for control. In: Sivakumar, M.V.K., Zöbisch, M., Koala, S., Maukonen, T. (Eds.), Wind Erosion in Africa and West Asia: Problems and Control Strategies. Proceedings of the Expert Group Meeting, 22-25 April 1997, Caïro, Egypt. ICARDA, Aleppo, Syria, pp. 13-33.

Mainguet, M., Chemin, M.C., 1991. Wind degradation on the sandy soils of the Sahel of Mali and Niger and its part in desertification. Acta Mech. 2, 113-130.

Manu, A., Geiger, S.C., Pfordresher, A., Taylor-Powell, E., Mahamane, S., Ouattara, M., Issaka, M., Salou, M., Juo, A.S.R., Puentes, R., Wilding, L.P., 1991. Aménagement intégré des bassins versants agricoles. Caractérisation d'un site de recherche près de Hamdallaye, Niger. Rep. No. 91-03. Soil Management CRSP. North Carolina State Univ., Raleigh, NC, USA, p. 82.

McTainsh, G.H., Walker, P.H., 1982. Nature and distribution of Harmattan dust. Z. Geomorphol., NF 26, $417-$ 435.

Michels, K., Sivakumar, M.V.K., Allison, B.E., 1995. Wind erosion control using crop residue: I. Effects on soil flux and soil properties. Field Crops Res. 40, 101-110.

Middleton, N., Thomas, D., UNEP, 1997. World Atlas of Desertification. 2nd edn. Arnolds, London, UK.

Nelson, D.W., Sommers, L.E., 1982. Total carbon, organic carbon, and organic matter. In: Page, A.L., Miller, R.H., Keeney, D.R. (Eds.), Methods of Soil Analysis. Part II. Chemical and Microbiological Properties. ASA and SSSA, Madison, WI, USA, pp. 539-582.

Olsen, S.R., Sommers, L.E., 1982. Phosphorus. In: Page, A.L., Miller, R.H., Keeney, D.R. (Eds.), Methods of Soil Analysis. Part II. Chemical and Microbiological Properties. ASA and SSSA, Madison, WI, USA, pp. $403-430$.

Rajot, J.L., 2001. Wind blown sediment mass budget of Sahelian village land units in Niger. Bull. Soc. Geol. Fr. $172,523-531$.

Sivakumar, M.V.K., Zöbisch, M., Koala, S., Maukonen, T., 1998. Wind Erosion in Africa and West Asia: Problems and Control Strategies. ICARDA, Aleppo, Syria, p. 198. 
Sterk, G., Haigis, J., 1998. Farmer's knowledge of wind erosion processes and control methods in Niger. Land Degrad. Dev. 9, 107-114.

Sterk, G., Raats, P.A.C., 1996. Comparison of models describing the vertical distribution of wind-eroded sediment. Soil Sci. Soc. Am. J. 60, 1914-1919.

Sterk, G., Herrmann, L., Bationo, A., 1996. Wind-blown nutrient transport and soil productivity changes in Southwest Niger. Land Degrad. Dev. 7, 325-335.

Stout, J.E., 1990. Wind erosion within a simple field. Trans. ASAE 33, 1597-1600.

Stout, J.E., Zobeck, T.M., 1996. The Wolfforth field experiment: a wind erosion study. Soil Sci. 161, 616-632.

Van Dijk, P.M., Arens, S.M., Van Boxel, J.H., 1999. Aeolian processes across transverse dunes: II. Modelling the sediment transport and profile development. Earth Surf. Processes Landf. 24, 319-333.

Zingg, A.W., 1953. Wind tunnel studies of the movement of sedimentary material. Proc. 5th Hydraul. Conf., State Univ. Iowa Stud. Eng. Bull., vol. 34, pp. 111-135.

Zobeck, T.M., Fryrear, D.W., 1986. Chemical and physical characteristics of windblown sediment: II. Chemical characteristics and total soil and nutrient discharge. Trans. ASAE 29, 1037-1041. 